\title{
MEKANISME TRANSAKSI DAN SISTEM PERHITUNGAN BUNGA KREDIT USAHA MIKRO KECIL DAN MENENGAH (UMKM) PADA PT. PEGADAIAN (PERSERO) CABANG ULAK KARANG
}

\author{
Resweni, Afriyeni \\ Akademi Keuangan dan Perbankan Padang \\ Afriyeni.yen@gmail.com
}

\begin{abstract}
ABSTRAK
Tujuan dari penelitian ini untuk mengetahui mekanisme transaksi dan untuk mengetahui sistem perhitungan bunga kredit UMKM pada PT. Pegadaian (PERSERO) Cabang Ulak Karang. Data yang digunakan dalam penelitian ini adalah dengan mewawancarai langsung pihak-pihak yang berkepentingan dalam hal ini adalah perusahaan yang terkait. Adapaun teknik pengumpulan data yaitu dengan studi lapangan dan studi perpustakaan. Metode penelitian ini yaitu dengan menggunakan analisa data kualitatif dan kuantitatif. dimana metode kualitatif menggambarkan, memahami dan menjelaskan data yang diteliti selama penelitian berlangsung, sedangkan metode kuantitatif yaitu menganalisa perhitungan bunga kredit Usaha Mikro Kecil dan Menengah (UMKM) pada PT. Pegadaian (PERSERO). Hasil dari penelitian ini adalah untuk membantu dan memudahkan masyarakat khususnya golongan ekonomi menengah kebawah, yang mempunyai usaha untuk memperluas atau mengembangkan usahanya, meningkatkan kapasitas produksi serta membuka peluang usaha baru. Transaksi dan persyaratan kredit ini cukup mudah dan dapat diproses dalam kurun waktu 3 hari. Barang yang bisa dijadikan agunan yaitu BPKB asli kendaraan bermotor dan kendaraan tersebut masih bisa dipergunakan oleh nasabah untuk membantu menjalankan usahanya, jangka waktu kredit ini 12-36 bulan, dengan sewa modal yang relative murah yaitu $1 \%$ per bulan yang dihitung secara flat (tetap). Dimana saat awal pembayaran kredit sampai dengan akhir kesepakatan perjanjian kredit dibayar dengan jumlah yang sama setiap bulannya.
\end{abstract}

\section{LATAR BELAKANG}

PT. Pegadaian (PERSERO) sebagai salah satu Badan Usaha Milik Negara (BUMN) yang bergerak dibidang usaha menyalurkan kredit secara hukum gadai kepada masyarakat (terutama masyarakat kecil dan menengah), berusaha merespon hal tersebut dengan meluncurkan suatu bentuk kredit yang mampu menjembatani kebijakan pemerintah dan kebutuhan masyarakat. Menurut Kitab Undang-Undang Hukum Perdata pasal 1150, gadai adalah hak yang diperoleh seseorang yang mempunyai piutang atas suatu barang baik yang bergerak maupun yang tidak bergerak.

Menurut (Kasmir, 2008:96) PT. Pegadaian sebagai lembaga perkreditan uang memiliki tujuan khusus yaitu penyaluran uang pinjaman atas dasar hukum gadai yang ditujukan untuk mencegah praktek rentenir dan sistem ijon yang cenderung memanfaatkan kebutuhan dana mendesak serta pinjaman tidak wajar lainnya yang merugikan masyarakat. 
PT. Pegadaian (PERSERO) dapat memberikan pinjaman kepada masyarakat luas dengan tujuan ikut membantu program pemerintah dalam upaya meningkatkan kesejahteraan khususnya golongan ekonomi menengah kebawah, pada PT. Pegadaian (PERSERO) Cabang Ulak Karang salah satu produk kredit yang diberikan adalah pemberian kredit untuk Usaha Mikro Kecil dan Menengah (UMKM) atau dalam PT. Pegadaian (PERSERO) produk ini disebut dengan Kredit Usaha dengan Sistem Fidusia (KREASI), yaitu merupakan pemberian pinjaman kepada para pengusaha Mikro Kecil dan Menengah (dalam rangka pengembangan usaha) atas dasar gadai dengan pengembalian pinjaman dilakukan melalui mekanisme angsuran. Dimana kredit yang diberikan kepada pengusaha mikro kecil dan menengah untuk keperluan mengembangkan usaha, meningkatkan kapasistas produksi serta membuka peluang usaha baru.Biasanya barang yang dijadikan agunan yaitu BPKB kendaraan bermotor, barang yang dijadikan agunan tetap berada dalam penguasaannya (nasabah) sehingga masih tetap dapat dimanfaatkan. Kredit usaha ini berjangka waktu minimal 12 bulan dan maksimal 36 bulan dengan pengembalian kredit dilakukan secara angsuran/cicilan tiap bulan dengan tingkat bunga (sewa modal) $1 \%$ yang dihitung secara flat (tetap) maksudnya sistem perhitungan suku bunga yang besarannya mengacu pada pokok hutang awal saja, pinjaman modal mulai dari Rp. 1.000.000 hingga Rp. 200.000.000. Pencairan kredit hanya dalam waktu 3 hari.

Kebijaksanaan perkreditan PT. Pegadaian (PERSERO) mengandung tingkat resiko tertentu, seperti munculnya kredit macet. Untuk itu supaya tidak terjadi kredit macet dan sebelum nasabah melakukan transaksi dalam pemberian Kredit UMKM, PT. Pegadaian (PERSERO) harus bisa menilai dan mengambil keputusan terhadap suatu permohonan kredit yaitu dengan berbagai aspek yang harus dipertimbangkan oleh pihak PT. Pegadaian (PERSERO) seperti pihak PT. Pegadaian (PERSERO) melakukan survey ke tempat lokasi usaha nasabah. Berikut merupakan jumlah plafond serta angsuran yang harus dibayar nasabah dengan ketentuan yang telah ditetapkan oleh pihak PT. Pegadaian (PERSERO)

Tabel 1

Simulasi Pembiayaan Kredit UMKM (KREASI)

(Rupiah)

\begin{tabular}{|r|r|r|r|r|}
\hline \multirow{2}{*}{ Pembiayaan } & \multicolumn{4}{|c|}{ Angsuran Bulanan } \\
\cline { 2 - 5 } & 12 bulan & 18 bulan & 24 bulan & 36 bulan \\
\hline 1.000 .000 & 93.400 & 65.600 & 51.700 & 37.800 \\
\hline 3.000 .000 & 280.000 & 196.700 & 155.000 & 113.400 \\
\hline 5.000 .000 & 466.700 & 327.800 & 258.400 & 188.900 \\
\hline 7.500 .000 & 700.000 & 491.700 & 387.500 & 283.400 \\
\hline 10.000 .000 & 933.400 & 655.600 & 516.700 & 377.800 \\
\hline 15.000 .000 & 1.400 .000 & 983.400 & 775.000 & 566.700 \\
\hline 30.000 .000 & 2.800 .000 & 1.966 .700 & 1.550 .000 & 1.133 .400 \\
\hline 50.000 .000 & 4.666 .700 & 3.277 .800 & 2.583 .400 & 1.888 .900 \\
\hline 75.000 .000 & 7.000 .000 & 4.916 .700 & 3.875 .000 & 2.833 .400 \\
\hline 100.000 .000 & 9.333 .400 & 6.555 .600 & 5.166 .700 & 3.777 .800 \\
\hline 150.000 .000 & 14.000 .000 & 9.833 .400 & 7.750 .000 & 5.666 .700 \\
\hline 200.000 .000 & 18.666 .700 & 13.111 .200 & 10.333 .400 & 7.555 .600 \\
\hline
\end{tabular}

Sumber : PT. Pegadaian (PERSERO) Cabang Ulak Karang 
Rumusan Masalah

a. Bagaimana mekanisme transaksi kredit UMKM pada PT.Pegadaian (PERSERO) Cabang Ulak Karang?

b. Bagaimana sistem perhitungan bunga kredit UMKM pada PT.Pegadaian (PERSERO) Cabang Ulak Karang?

\section{TINJAUAN PUSTAKA}

Menurut Undang-Undang Perbankan Nomor 10 Tahun 1998 tentang perubahan Undang-Undang Nomor 7 Tahun 1992 pengertian kredit adalah penyediaan uang atau tagihan-tagihan yang dapat dipersamakan dengan itu berdasarkan persetujuan atau kesepakatan pinjam-meminjam antara bank dengan pihak lain yang mewajibkan pihak peminjam untuk melunasi utangnya setelah jangka waktu tertentu dengan pemberian bunga, imbalan atau bagi hasil keuntungan.

Pemberian kredit adalah tulang punggung kegiatan PT. Pegadaian (PERSERO), pendapatan terbesar dari usaha PT. Pegadaian (PERSERO) adalah sewa modal dari pemberian kredit. Pemberian kredit yang tinggi akan menentukan keuntungan bagi PT. Pegadaian (PERSERO), dan pengembalian kredit yang diberikan dilakukan pada saat jatuh tempo dan ditambah dengan sewa modal yang ditentukan.

Adapun unsur-unsur kredit yaitu :

a. Kepercayaan, yaitu adanya rasa saling percaya antara kreditur dan debitur.

b. Jangka waktu, yaitu limit waktu pengembalian kredit yang telah disepakati antara kreditur dengan debitur.

c. Resiko, yaitu menyangkut lamanya waktu pemberian kredit yang menyebabkan naiknya tingkat resiko yang timbul.

d. Prestasi, yaitu bagaimana tindakan yang dilakukan oleh pihak debitur dalam usahanya atau prestasinya mengelola kredit yang diberikan tersebut.

e. Kreditur, yaitu pihak yang memiliki uang, barang atau jasa untuk dipinjamkan kepada pihak debitur.

f. Debitur, yaitu pihak yang memerlukan uang, barang atau jasa dan mampu mengembalikannya tepat sesuai dengan waktu yang disepakati.

Tujuan dari kredit yaitu :

a. Mencari keuntungan yang tujuannya memperoleh hasil dari pemberian kredit tersebut.

b. Membantu usaha nasabah, tujuannya membantu usaha nasabah yang memerlukan dana untuk modal usaha.

c. Membantu pemerintah, tujuannya untuk peningkatan pembangunan di berbagai sektor.

Fungsi dari kredit yaitu :

a. Untuk meningkatkan daya guna uang

b. Untuk meningkatkan peredaran dan lalu lintas uang

c. Untuk meningkatkan daya guna dan peredaran barang

d. Sebagai alat stabilitas ekonomi

e. Untuk meningkatkan kegairahan berusaha

f. Untuk meningkatkan pemerataan pendapatan 
Jenis-jenis kredit yang dapat diberikan pada masyarakat berdasarkan pengelompokan sebagai berikut :

a. Berdasarkan jangka waktu

1) Kredit jangka pendek (short term credit)

2) Kredit jangka waktu menengah (medium term credit)

3) Kredit jangka panjang (long term credit)

b. Berdasarkan jenisnya

1) Kredit produktif

2) Kredit konsumtif

3) Kredit perdagangan

c. Berdasarkan jaminan

1) Kredit dengan jaminan (secured loans)

2) Kredit tanpa jaminan (insecured loans)

d. Berdasarkan kualitas

1) Kredit performing

2) Kredit non performing

Dalam prinsip penilaian kredit dapat dilakukan dengan analisa 5C yaitu :

a. Character (watak), yaitu menilai watak kehidupan calon nasabah meliputi kebiasaan-kebiasaan, sifat pribadi, cara hidup, keadaan keluarga, hobby, dan lain sebagainya.

b. Capacity (kemampuan), yaitu menilai apakah calon nasabah tersebut mempunyai kemampuan dan pengalaman bisnis untuk memajukan usahanya setelah diberi kredit.

c. Capital (modal), yaitu pihak kreditur biasanya tidak bersedia untuk membiayai suatu kegiatan dalam jumlah $100 \%$ jadi calon nasabah harus mampu menyediakan modal sendiri.

d. Collateral (jaminan), yaitu untuk meyakinkan kredit jaminan merupakan hal yang utama kalau terjadi kesangsian, dalam pertimbangan-pertimbangan lain.

e. Condition (keadaan), yaitu pihak kreditur hendaknya melihat programprogram pemerintah, kebijaksanaan-kebijaksanaan pemerintah terutama dalam bidang perekonomian.

Menurut Divisi Usaha Syariah PT. Pegadaian (PERSERO), Kreasi (Kredit Angsuran Fidusia) adalah pinjaman (kredit) dalam jangka waktu tertentu dengan menggunakan konstruksi penjaminan kredit secara jaminan fidusia, yang diberikan oleh PT. Pegadaian (PERSERO) kepada pengusaha mikro dan pengusaha kecil yang membutuhkan dana untuk keperluan pengembangan usahanya.

Fidusia adalah pengalihan hak kepemilikan suatu benda atas dasar suatu kepercayaan, dengan ketentuan bahwa benda yang hak kepemilikannya dialihkan tersebut tetap dalam penguasaan pemilik benda (Undang-Undang No. 42 Tahun 1999 tentang Fidusia pasal 1 angka 1).

Pada dasarnya semua jenis usaha mikro kecil bisa didanai dengan kredit kreasi, kecuali jenis usaha yang bergerak pada industri dengan kriteria dibawah ini, dilarang untuk didanai dengan Kredit Kreasi yaitu :

a. Kegiatan usaha dibidang industri yang permintaan produknya fluktuatif : 
1) Usaha jasa pialang saham

2) Usaha jasa di bursa komoditi

3) Usaha jasa perdagangan valas informal

4) Usaha maya (bisnis melalui internet)

5) Usaha sejenis lainnya

b. Kegiatan usaha dibidang industri yang pertumbuhannya sedang lesu/menurun, seperti :

1) Usaha perunggasan saat terjadi wabah flu burung, antara lain : usaha ternak ayam, bebek, burung puyuh, kalkun dan lain-lain.

2) Usaha ternak sapi/kerbau/kambing pada saat terjadinya wabah penyakit mulut kuku/sapi gila ataupun anthrax.

3) Usaha industri lainnya yang tingkat permintaan pasarnya sedang menurun.

c. Kegiatan usaha dibidang industri yang tidak sejalan dengan etika dan norma pergaulan sosial masyarakat Indonesia, seperti usaha pelacuran, usaha perjudian/Bandar togel dan lain-lain.

d. Kegiatan usaha dibidang industri yang memproduksi barang/jasa yang tidak ramah lingkungan, seperti usaha penambangan liar, usaha penebangan kayu liar dan lain-lain.

e. Kegiatan usaha dibidang industri yang kegiatannya tidak umum/pasarnya tidak jelas, seperti usaha dukun/paranormal, usaha pengobatan alternative dan usaha sejenis lainnya.

f. Kegiatan usaha dibidang industri yang memproduksi barang/jasa illegal, seperti usaha perdagangan narkoba, usaha perbudakan dan usaha sejenis lainnya.

g. Usaha-usaha yang laku sesaat, investasi rendah dan mudah ditiru, antara lain : budidaya jamur, budidaya jati emas, peternakan burung perkutut dan lainlain.

h. Usaha setempat yang tingkat persaingan keras dan pasarnya mudah jenuh, seperti produk-produk pengrajin yang mudah ditiru dan pasarnya terbatas.

\section{METODE PENELITIAN}

Dalam pengumpulan data dan bahan untuk penelitian ini digunakan metode penelitian sebagai berikut :

\section{a. Metode Pengumpulan Data}

1) Study Lapangan (Field Research)

Peninjauan langsung ke objek penelitian yang dipilih untuk meneliti hasil data tersebut. Penelitian langsung ke lapangan ini akan dapat membantu penulis untuk melengkapi data yang diperlukan. Adapun cara riset lapangan ini adalah dengan mewawancarai langsung pihak-pihak yang berkepentingan dalam hal ini adalah perusahaan yang terkait.

2) Study Perpustakaan (Library Research)

Penelitian ini dilakukan ke perpustakaan berupa buku-buku ilmiah dan tulisan-tulisan yang berhubungan dengan pembahasan yang dilakukan. 


\section{b. Metode Analisa Data}

Dalam menganalisa data, menggunakan analisa data kualitatif dan kuantitatif. dimana metode kualitatif menggambarkan, memahami dan menjelaskan data yang diteliti selama penelitian berlangsung, sedangkan metode kuantitatif menganalisa perhitungan bunga kredit usaha mikro kecil dan menengah (UMKM) pada PT. Pegadaian (PERSERO) Cabang Ulak Karang atau di PT. Pegadaian (PERSERO) sering disebut Kredit Kreasi.

\section{HASIL DAN PEMBAHASAN}

\section{a. Mekanisme Transaksi Kredit UMKM}

1) Dengan kedatangan calon nasabah ke bagian pegawai fungsional untuk meminta penjelasan tentang kredit usaha dan meminta formulir permohonan kredit (form-1) untuk diisi. Setelah mengisi form permintaan kredit dan melengkapi persyaratan yang telah ditetapkan, selanjutnya calon nasabah menyerahkan kepada pegawai fungsional.

2) Pegawai fungsional mengirimkan persyaratan tersebut ke Tim Mikro Area. Hal pertama yang dilakukan adalah melakukan penelitian awal dengan menanyakan seputar usaha yang dimiliki oleh calon nasabah dan melakukan peninjauan domisili/lokasi usaha (survey) serta melakukan pengecekan/pemeriksaan barang yang di agunkan (BPKB Kendaraan Bermotor).

3) Setelah dinyatakan lolos uji analisa kredit oleh Tim Mikro Area, setelah itu Kuasa Pemutus Kredit (KPK) menetapkan kredit yang akan diterima oleh nasabah, dimana Kuasa Pemutus Kredit (KPK) menetapkan jumlah kredit yang akan diterima nasabah. Setelah nasabah menyetujui kredit tersebut lalu dilanjutkan dengan menandatangani perjanjian hutang piutang (form-3) yang harus dihadiri oleh suami istri, membuat surat pernyataan, surat penjamin kendaraan dan surat lain yang dianggap perlu. Nasabah yang telah menandatangani surat-surat yang diperlukan kemudian nasabah menerima surat perjanjian hutang piutang (form-3), bukti penerimaan uang (form-5) rangkap 3 dan kartu angsuran kredit usaha.

4) Selanjutnya perjanjian tersebut diberikan kepada notaris yang telah ditunjuk oleh pihak PT. Pegadaian (PERSERO) Cabang Ulak Karang.

5) Lalu nasabah menghubungi kasir untuk mencairkan kredit dengan menyerahkan form-3, form-5 dan kartu angsuran. Nasabah dipersilahkan menandatangani form-5 dihadapan kasir dan nasabah dapat menerima uang sebagai pencairan kredit berikut dengan form-3, selembar form-5 dan kartu angsuran. Uang yang diterima nasabah telah dipotong biayabiaya seperti biaya administrasi, biaya pendaftaran fidusia, biaya notaris, biaya checklist BPKB, biaya materai dan lainnya yang telah ditentukan.

\section{b. Sistem Perhitungan Bunga Kredit UMKM}

Untuk PT. Pegadaian (PERSERO) Cabang Ulak Karang sewa modal (bunga) yang diberikan sebesar $1 \%$ dan nasabah bebas untuk memilih jangka waktu pelunasan kredit tersebut. Jumlah pinjaman kredit usaha ini minimal Rp. 1.000.000 dan maksimal Rp. 200.000.000. Setiap cabang- 
cabang PT. Pegadaian (PERSERO) sudah ditentukan dan ditetapkan oleh PT. Pegadaian (PERSERO) pusat, seperti penetapan sewa modal serta plafond pinjaman kredit tersebut. Untuk rumus perhitungan angsuran Kredit UMKM (Kredit Kreasi), yaitu : (Sumber : PT. Pegadaian (PERSERO) Cabang Ulak Karang)

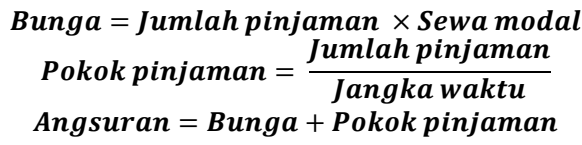

\section{SIMPULAN}

1) Mekanisme transaksi Kredit UMKM (Kredit Kreasi) pada PT. Pegadaian (PERSERO) Cabang Ulak Karang dari kedatangan calon nasabah ke perusahaan untuk memberikan berkas-berkas persyaratan kredit, berkas tersebut dikirim ke Tim Mikro Area untuk mensurvey lokasi usaha nasabah, setelah disurvey selanjutnya KPK (Kuasa Pemutus Kredit) menetapkan kredit dan nasabah menyetujui kredit tersebut, setelah adanya kesepakatan selanjutnya nasabah menandatangani perjanjian kredit yang harus dihadiri oleh suami istri, setelah menandatangani perjanjian kredit nasabah menghubungi kasir untuk mencairkan kredit yang telah disepakati bersama, setelah pencairan kredit selesai, perjanjian kredit yang telah disepakati tersebut diberikan kepada notaris yang telah ditunjuk oleh PT. Pegadaian (PERSERO) Cabang Ulak Karang.

2) Pemberian sewa modal Kredit UMKM (Kredit Kreasi) pada PT. Pegadaian (PERSERO) Cabang Ulak Karang telah sesuai dengan ketentuan-ketentuan yang ditetapkan antara besarnya jumlah pinjaman yang diberikan dengan besarnya pemberian sewa modal. Pada perhitungan angsuran Kredit UMKM (Kredit Kreasi) pada PT. Pegadaian (PERSERO) Cabang Ulak Karang telah sesuai menggunakan rumus yang ditetapkan dan jumlah angsuran yang diperoleh sesuai dengan besarnya pemberian sewa modal.

\section{DAFTAR PUSTAKA}

Adriansyah. A, Sistem Kredit, Bagian 2, Lembaga Perkembangan Perbankan Indonesia, 1992

Alanshari, F., \& Marlius, D. (2018). Prosedur Pemberian Kredit KPR Pada PT. Bank Tabungan Negara (Persero) TBK Cabang Pembantu Bukittinggi. https://doi.org/10.31227/osf.io/rsfhc

Amelia, L., \& Marlius, D. (2018). Pengendalian Kredit Dalam Upaya Menciptakan Bank Yang Sehat Pada PT. Bank Pembangunan Daerah Sumatera Barat Cabang Utama Padang. https://doi.org/10.31227/osf.io/kpc64 
Andriani, B., \& Susanto, R. (2019). Pengawasan Kredit PT. Bank Perkreditan Rakyat (BPR) Ophir Pasaman Barat. https://doi.org/10.31219/osf.io/aunvc

Baiya, \& Fernos, J. (2019). Analisis Faktor-Faktor Penyebab Kredit Macet Pada Bank Nagari Cabang Siteba. https://doi.org/10.31227/osf.io/4xuks

Darmawanto, \& Fernos, J. (2019). Prosedur Pemberian Kredit Pada Bank Nagari Cabang Sijunjung. https://doi.org/10.31227/osf.io/psqfy

Firmansyah, A., \& Fernos, J. (2019). Analisis Kredit Bermasalah Dilihat Dari Standar Non Performing Loan (NPL) Pada PT. Bank Perkreditan Rakyat (BPR) Prima Mulia Anugrah Cabang Padang. https://doi.org/10.31227/osf.io/gcj94

Fahmi Irham, Manajemen Perkreditan, Alfabeta, 2014

http://pegadaian.co.id

Ikbal, M., \& Marlius, D. (2017). Pengaruh Jumlah Taksiran Dan Uang Pinjaman Terhadap Laba Bersih Pada PT. Pegadaian (UPC) Gurun Laweh. https://doi.org/10.31227/osf.io/uch4a

Indrianto, Nur dan Bambang Supomo, 2002, Metodologi Penelitian Bisnis, Yogyakarta : BPFE

Kasmir, Bank dan Lembaga Keuangan Lainnya, edisi 6, PT. Raja Grafindo Persada

Moenir. A.S, 2001, Manajemen Pelayanan Umum, Bumi Aksara, Jakarta

Orlando, A., \& Susanto, R. (2019). Mekanisme Pencairan Kredit Usaha Rakyat Pada PT. Bank Rakyat Indonesia Unit Lubuk Buaya. https://doi.org/10.31219/osf.io/zuv2y

Pegadaian, Analisa Kredit Kelayakan Usaha Pegadaian, PT. Pegadaian, 2005

Pratama, D., \& Fernos, J. (2019). Prosedur Pelaksanaan Kredit Usaha Rakyat (KUR) Pada PT. Bank Nagari Cabang Padang. https://doi.org/10.31227/osf.io/ag68j

Suhardjono, 2003, Manajemen Perkreditan Usaha Kecil dan Menengah, Makasar : UPP AMP YKPN 
Shanjaya, A. R., \& Marlius, D. (2017). Peranan Laporan Keuangan Dalam Kebijaksanaan Pemberian Kredit Kepada Calon Nasabah Pada PT. BPR Batang Kapas. https://doi.org/10.31227/osf.io/uxmg6

Suyatno, Drs. Thomas, Dasar-Dasar Perkreditan, PT. Gramedia, 1989

Triandaru Sigit, Totok Budisantoso, Bank dan Lembaga Keuangan Lain, edisi 2, salemba empat

Undang-Undang Perbankan Nomor 10 Tahun 1998 tentang perubahan UndangUndang Nomor 7 Tahun 1992, Pengertian Kredit

Widayati, R. (2019). Penyelesaian Kredit Bermasalah Pada PT. Bank Perkreditan Rakyat (BPR) Nagari Kasang. https://doi.org/10.17605/OSF.IO/D4MF3

Widayati, R. (2019). Pelaksanaan Prinsip Kehati-Hatian Dalam Pemberian Kredit Konsumtif Pada Bank Nagari Cabang Siteba. https://doi.org/10.17605/OSF.IO/FZVXR

Widayati, R. (2019). Aktivitas Pemberian Kredit Komersil Pada Bank Nagari Cabang Sijunjung. https://doi.org/10.17605/OSF.IO/QTVZ9

Widayati, R. (2019). Pelaksanaan Kredit Pada Bank Perkreditan Rakyat LPN Pasar Baru Durian Sawahlunto. https://doi.org/10.17605/OSF.IO/5HPAB

Widayati, R. (2019). Upaya Penanganan Kredit Bermasalah Pada Bank Nagari Cabang Utama Padang. https://doi.org/10.17605/OSF.IO/YJ3KN

Widayati, R. (2019). Aktivitas Pemberian Kredit Usaha Pada PT. Bank Perkreditan Rakyat Batang Kapas. https://doi.org/10.17605/OSF.IO/EDPN4 